\title{
ISOLATION, CHARACTERIZATION, AND DETERMINATION OF ANTIOXIDATIVE PROPERTIES OF PROTEIN EXTRACTED FROM ROHU (LABEO ROHITA) FISH SKIN
}

\author{
NABANITA GHOSH*, BHATTACHARYYA DK \\ School of Community Science and Technology (SOCSAT), Indian Institute of Engineering Science and Technology, Shibpur, Howrah, India. \\ Email: naba1990@gmail.com
}

Received: 12 December 2019, Revised and Accepted: 10 January 2020

\begin{abstract}
Objective: Isolation, characterization and analysis of antioxidant activity of protein extracted from Labeo rohita skin.

Methods: The present work aimed to characterize protein isolated from Indian major carp L. rohita skin. Protein isolation was carried out by the saltingout method and the protein content was estimated with bovine serum albumin. Isolated protein was subjected to Fourier-transform infrared analyzer to identify the presence of $-\mathrm{NH}_{3}$ group to be claimed as protein. It was also subjected to high-performance liquid chromatography (HPLC) analyzer and run against standard collagen (Sigma), the molecular weight of the protein was determined through mass spectroscopy (MS) to know the protein structure more precisely the protein isolate was studied under a scanning electron microscope (SEM). Antioxidative activity of the crude protein sample was studied through 2,2-diphenyl-1-picrylhydrazyl, ferric reducing antioxidant potential (FRAP) assay, 2,2'-azino-bis(3-ethylbenzothiazoline-6-sulfonic acid) (ABTS) assay.
\end{abstract}

Results: The protein isolated was $23 \%$ of the dry weight of fish skin. In HPLC analysis, the isolated protein gives peaks that are similar to that of standard collagen, and in MS, its molecular weight was near about $300 \mathrm{kDa}$, which is the molecular weight of collagen type 1 . The SEM image shows a crystal structure of protein isolates. Results of antioxidative property show that fish skin protein isolates have good antioxidative activity also.

Conclusion: The isolated protein was collagen and it can be used as a replacer of the renowned market available collagen

Keywords: Protein, Collagen, Fish skin, 2,2-Diphenyl-1-picrylhydrazyl, ABTS, FRAP.

(c) 2020 The Authors. Published by Innovare Academic Sciences Pvt Ltd. This is an open access article under the CC BY license (http://creativecommons. org/licenses/by/4. 0/) DOI: http://dx.doi.org/10.22159/ajpcr.2020.v13i3.36615

\section{INTRODUCTION}

Collagen is the main protein constituent found in the skin of every higher animal. Collagen has numerous applications in pharmaceuticals, cosmetics, and the food industry [1]. The collagen protein is a long, stiff, and triplestranded helix, in which peptide chains are wrapped around one another to form a rope-like helix structure. These peptides are extremely rich in glycine and proline, which are very important amino acids [2]. Collagen is mainly extracted from the skins of ruminant and porcine livestock and poultry $[3,4]$. However, nowadays, interest has moved toward fish, jellyfish, marine sponge, and squid [5-8]. Collagen is extracted mainly from sea fish, whereas $41.24 \%$ of fish are found in freshwater. This high amount of fish skin is discarded as waste during fish processing, can be utilized for the production of collagen. Hence, an attempt has been made to isolate and characterize the protein from Labeo rohita skin and to identify the extracted protein, whether it is collagen or not through Fourier transform infrared (FT-IR), scanning electron microscope (SEM), high-performance liquid chromatography (HPLC), and mass spectroscopy (MS) study. Furthermore, the antioxidative properties of the crude protein were analyzed through 2,2-diphenyl-1-picrylhydrazyl (DPPH), FRAP, and ABTS assay.

\section{METHODS}

\section{Preparation of samples}

Fish skins were collected from the local market. It was washed thoroughly to remove dust particles and any sort of scales with first under tap water and then with distilled water. It was then cut into smaller pieces and kept at $-20^{\circ} \mathrm{C}$ until further use.

\section{Isolation of protein}

The skin was dried and dissolved in n-hexane in 1:10 (w/v) ratio for $24 \mathrm{~h}$ to remove the lipid part from the skin. Protein was extracted from fish skin through the salting-out method [9] with modification. Fish skins were stirred with $\left.0.1 \mathrm{~N} \mathrm{NaHCO}_{3} 1: 10\right)$ for $6 \mathrm{~h}$ followed by centrifugation at $6000 \mathrm{rpm}$ for $20 \mathrm{~min}$. The pellet was collected and again stirred with $0.5 \mathrm{~N} \mathrm{CH}_{3} \mathrm{COOH}$ (1:10) for $24 \mathrm{~h}$ and centrifuged at $6000 \mathrm{rpm}$ for $20 \mathrm{~min}$. The supernatant was collected and protein was extracted, which was by salting out with $\mathrm{NaCl}$ until the final concentration of the solution becomes $0.7 \mathrm{~N} / \mathrm{L}$. The precipitate was collected as crude protein and lyophilized for further use.

\section{Characterization of fish skin protein \\ FT-IR analysis}

FT-IR analysis of the lyophilized samples was carried out to identify the functional group present in the sample. As the sample was claimed to be protein, the presence of $-\mathrm{NH}_{3}$ group is a parameter to establish it as protein. The presence or absence of $-\mathrm{NH}_{3}$ is detected through FT-IR analysis. FT-IR analysis of the lyophilized sample was carried out on FTIR - 4600 type A, serial no-D060661786 with triglycine sulfate detector. Spectrum was recorded between wavenumber 0 and $7800.65 \mathrm{~cm}^{-1}$.

\section{HPLC analysis}

The identification of the crude protein sample was carried out in an HPLC analyzer. The HPLC apparatus was from Waters, model no. 2695. The detection was carried out using $\mathrm{C}_{18}$ column and 2487 dual detector, with a run time of $1 \mathrm{ml} / \mathrm{min}$ and a wavelength of 280/210/370 $\mathrm{nm}$. The same was done for standard collagen (Sigma) and compared with the sample.

\section{MS analysis}

MS analysis was carried out to detect the molecular weight of the crude protein sample. The test was performed by gradient method in an MS apparatus from Waters, model no. XEVO G2-XS QTof, BEH $\mathrm{C}_{18}$ column, and photodiode array (PDA) detector with a run time of $1 \mathrm{ml} / \mathrm{min}$ at 
$254 \mathrm{~nm}$ absorbance. The sample had given peaks and that is similar to the molecular weight of collagen.

\section{SEM image analysis}

Scanning electron microscopy of the crude protein was done in a SEM with gold coating and the SEM images resemble with that of collagen.

\section{Antioxidative property analysis}

Antioxidative properties of the crude sample were determined to evaluate the radical scavenging activity of crude protein through DPPH, FRAP, ABTS [10], and reducing power assay [11].

\section{DPPH free radical scavenging activity}

A volume of $2 \mathrm{~mL}$ of a methanolic solution of the crude protein was put into test tubes and $2 \mathrm{~mL}$ of $1 \mathrm{mM}$ DPPH solution was added. The tubes were kept in the dark for $1 \mathrm{~h}$. Absorbance at $517 \mathrm{~nm}$ was measured with a spectrophotometer (JASCO V-630) and compared to an ascorbic acid calibration curve. The results were expressed as mg ascorbic acid/g of sample. The percentage inhibition of the DPPH radical was calculated using the following formula:

$$
\mathrm{I} \%=\frac{\left(\mathrm{A}_{0}-\mathrm{A}\right)}{\mathrm{A}_{0}} \times 100
$$

Where, $\mathrm{I}=\mathrm{DPPH}$ inhibition (\%), $\mathrm{A}_{0}=$ absorbance of control sample $(\mathrm{t}=0 \mathrm{~h})$, and $\mathrm{A}=$ absorbance of a tested sample at the end of the reaction $(\mathrm{t}=1 \mathrm{~h})$.

Determination of FRAP (ferric reducing/antioxidant power) activity The antioxidant activity by FRAP assay was carried out by the method of the ferric reducing ability of plasma (FRAP) assay of Benzie and Strain, 1996, with slight modifications. Twenty microliters of sample and 180 $\mu \mathrm{L}$ of FRAP reagent were incubated at $37^{\circ} \mathrm{C}$ for $40 \mathrm{~min}$ in the dark. The absorbance of the resulting solution was measured at $593 \mathrm{~nm}$ in an ultraviolet spectrophotometer (JASCO V-630). The change in absorbance between the final reading ( 4 min reading) and blank reading $(0 \mathrm{~min}$ reading) of the sample and the same of standard ascorbic acid was selected for the calculation of FRAP value which is calculated using the formula:

FRAP value $=($ sample changes from 0 to $4 \mathrm{~min} /$ standard changes from 0 to $4 \mathrm{~min}$ ) $\times$ FRAP value of standard

ABTS (2,2'-azinobis-3-ethylbenzenethiazoline-6-sulfonic acid) decolorization method

The antioxidant activity by the ABTS method was performed using a volume of $20 \mu \mathrm{L}$ (diluted 1:10) of crude protein extract added to $2 \mathrm{~mL}$ of ABTS solution, and the mixture was kept at room temperature for $10 \mathrm{~min}$.

Table 1: Proximate composition of Labeo rohita skin

\begin{tabular}{ll}
\hline Component & Amount (\%) \\
\hline Moisture & $45.25 \pm 0.27$ \\
Ash & $2.70 \pm 0.01$ \\
Carbohydrate & $2.15 \pm 0.02$ \\
Protein & $24.50 \pm 0.03$ \\
Fat & $25.40 \pm 0.02$ \\
\hline
\end{tabular}

All tests were performed in triplets. Data are expressed as Mean \pm SD (standard deviation)

Table 2: Antioxidative property of FPI

\begin{tabular}{ll}
\hline Test performed & Amount \\
\hline DPPH & $47.36 \%$ \\
FRAP & $10 \mu \mathrm{g}$ of AAE/g \\
ABTS & $35.57 \%$ \\
Reducing power & $1.030-1.313$ \\
\hline
\end{tabular}

FPI: Fish protein isolate, DPPH: 2,2-Diphenyl-1-picrylhydrazyl
The absorbance was measured at $734 \mathrm{~nm}$ with a spectrophotometer (JASCO V-630). The values were compared with those of the butyl hydroxytoluene standard curve. The result was calculated using the following formula:

$$
\% \text { Antioxidant activity }=\frac{A_{c}-A_{s}}{A_{c}} \times 100
$$

Where, $A_{c}$ and $A_{s}$ are the absorbance of control and sample, respectively.

\section{Reducing power assay}

It was measured according to the method of Oyaizu. In a test tube, $2.5 \mathrm{ml}$ crude protein extract, $2.5 \mathrm{ml}$ sodium phosphate buffer $(0.2 \mathrm{M})$, and $2.5 \mathrm{ml}$ potassium ferricyanide were mixed and incubated in a water bath for $20 \mathrm{~min}$ at $50^{\circ} \mathrm{C}$. After that, $2.5 \mathrm{ml}$ trichloroacetic acid was
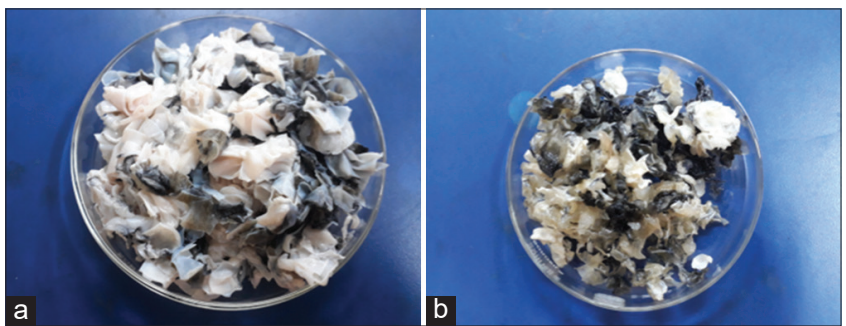

Fig. 1: (a) Fish skin collected from the local market. (b) Scales are isolated from the fish skin

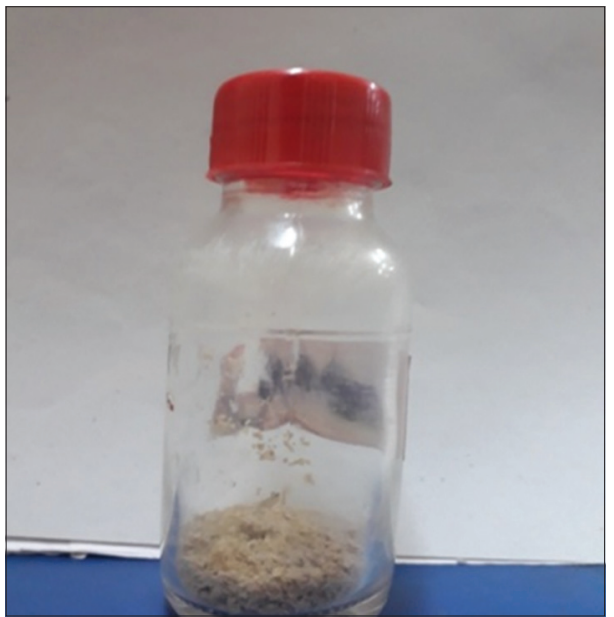

Fig. 2: Crude protein powder

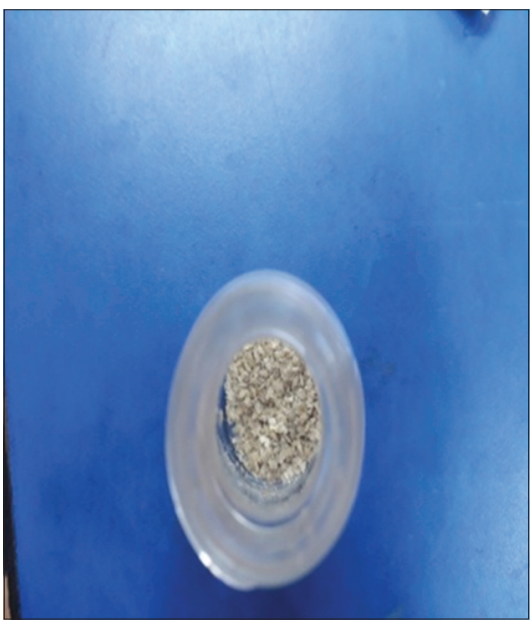

Fig. 3: Close view of crude protein powder 
added. The mixture was centrifuged for $10 \mathrm{~min}$ and the supernatant was taken into a test tube, in which $5 \mathrm{ml}$ distilled water and $1 \mathrm{ml}$ ferric chloride were added. Absorbance was measured at $700 \mathrm{~nm}$. An increase in absorbance of the reaction mixture indicates an increase in reducing the power of the test sample.

\section{RESULTS}

Proximate composition of fish skin

Fish skins were subjected to proximate composition to reveal the major nutrient component of the skin. The results of the proximate composition analysis are mentioned in Table 1. Rohu skin contains about $24.50 \pm 0.03 \%$ of protein which is quite a good amount. Fig. 1a and $b$ shows the picture of fish skin collected from the market and after the scale is removed from the skin, respectively.

\section{Protein yield}

From $40 \mathrm{~g}$ of fish skin, sample $9.8 \mathrm{~g}$ crude protein was recovered and hence the protein yield is $24.5 \%$. Figs. 2 and 3 imply the picture of lyophilized and powdered protein samples.

\section{FT-IR analysis}

The FT-IR spectrum of Rohu fish skin protein is represented in Fig. 4. The FT-IR spectrum exhibits a bands of amide A (associated with N-H groups and involved in hydrogen bonds of peptide), amide B (related to the asymmetric stretching of $\mathrm{C}-\mathrm{H}$ ), amide I (associated with stretching vibrations of the $\mathrm{C}=\mathrm{O}$ and an indication of secondary structure of peptides), amide II (attribute stretching of the carbonyl group coupled to a carbonyl group), and amide III (stretching vibration between C-N and bending vibration of $\mathrm{N}-\mathrm{H}$ ) at different wavelength. The standard amide II band is supposed to be occurred at $1550 \mathrm{~cm}^{-1}$ and 1600 $\mathrm{cm}^{-1}$ [12]. In case of Rohu skin, it also shows a band near $1533 \mathrm{~cm}^{-1}$. The FT-IR spectrum of collagen protein reported in the previous work [13] indicated that the band for amide I is in between 1644 and $1653 \mathrm{~cm}^{-1}$, amide II is in 1541 and $1548 \mathrm{~cm}^{-1}$, and for amide III, it is $1237-1239 \mathrm{~cm}^{-1}$, band of amide A is in between 3304 and $3315 \mathrm{~cm}^{-1}$, and for amide B, it is 2922 and $2940 \mathrm{~cm}^{-1}$. Protein isolated from Rohu skin exhibits bands in nearly wavelength of $1640.16 \mathrm{~cm}^{-1}$ and $1734.66 \mathrm{~cm}^{-1}$, that is, for amide I, at $1257.36 \mathrm{~cm}^{-1}$ for amide III, at $3486.67 \mathrm{~cm}^{-1}, 3254.29 \mathrm{~cm}^{-1}$, and $3047.94 \mathrm{~cm}^{-1}$ for amide A, and at $2859.92 \mathrm{~cm}^{-1}, 2947.66 \mathrm{~cm}^{-1}$, and $2921.63 \mathrm{~cm}^{-1}$ for amide B. The FT-IR spectrum indicates that the isolated protein gives a similar wavelength of collagen.

\section{HPLC analysis}

HPLC analysis of Rohu skin is given in Fig. 5. It gives the retention time (RT) for different protein chains of $a_{1}(I), a_{2}(I), a_{3}(I I), a_{1}(I I I), a_{3}$ (IV), and $\mathrm{a}_{2}(\mathrm{~V})$. Standard RT for the protein chains is 13.7, 13.9, 12.7, 13.0, 20.1, and $12.3 \mathrm{~min}$, respectively [14]. Rohu skin protein isolate gives RT of $11.174,11.319$, and $15.389 \mathrm{~min}$, which is close to that of standard collagen. Depending on the HPLC result, it can be stated that the protein can be of collagen

\section{MS analysis}

The mass spectrum of the protein isolate is mentioned in Fig. 6. X-axis of a mass spectrum indicates mass-charge ratio and Y-axis represents the signal intensity of the ions. The mass spectrometric analysis produces fragments of molecular weights which is called peak list. The mass of these peptide fragments is calculated and compared to that of a standard. Collagen I possesses $\alpha_{1}$ and $\alpha_{2}$ subunit at a molecular weight of 116.5-126 KDa and 255.5-281.1 KDa, respectively, and a $\beta$ subunit approximately at $417.3 \mathrm{KDa}$ [15]. The molecular weight of Rohu skin protein isolate falls in this range.

\section{SEM analysis}

SEM image of the protein represents in Fig. 7 and it gives a crystalline structure of the protein. In the previous work [16], SEM image showed

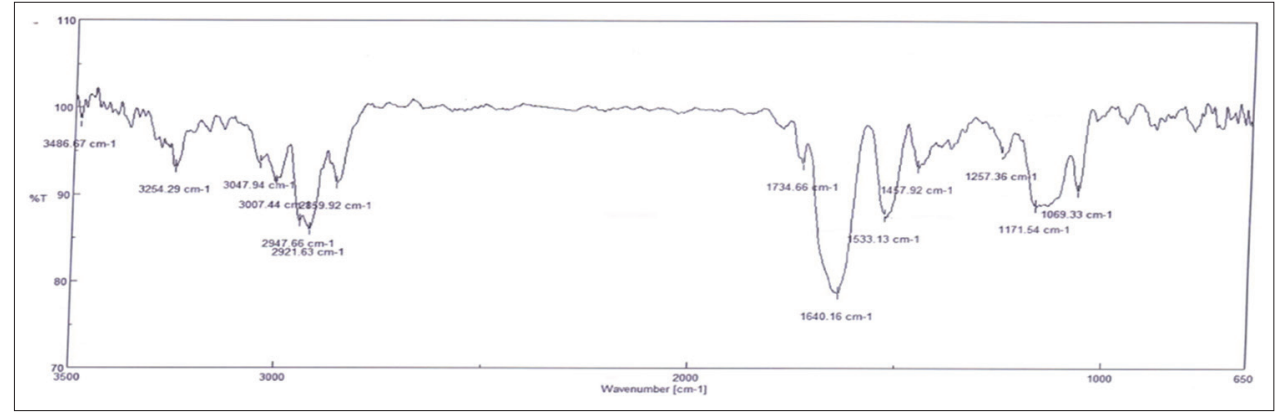

Fig. 4: Fourier transform infrared spectrum of Rohu skin protein isolate

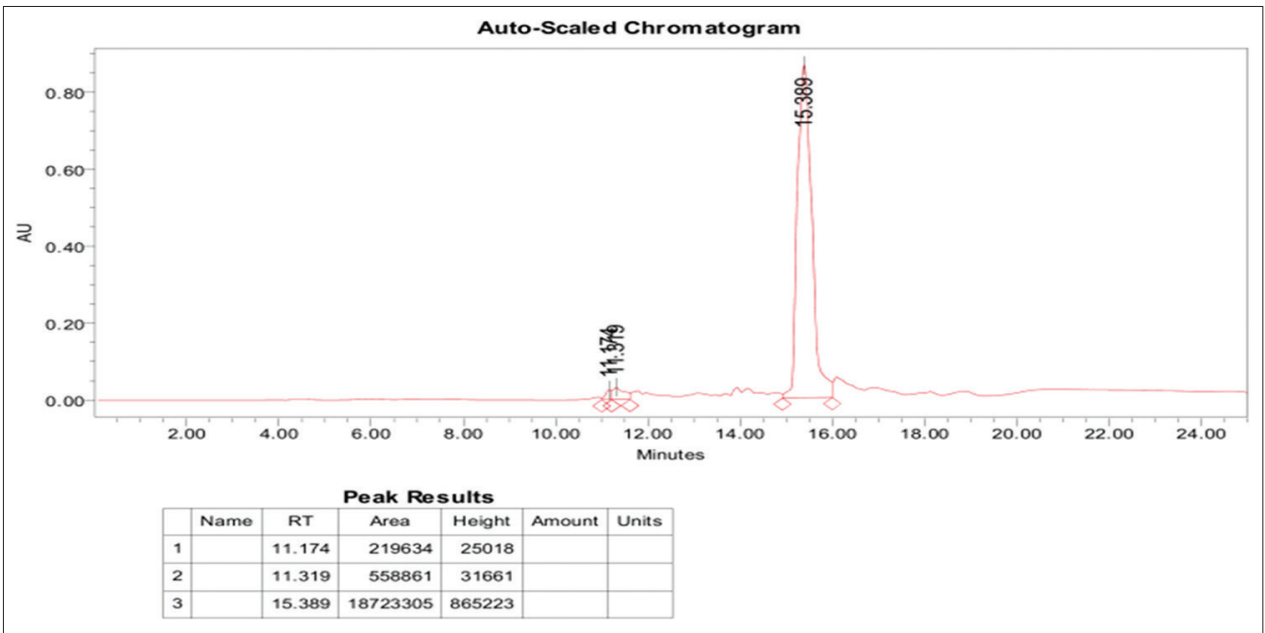

Fig. 5: High-performance liquid chromatography of Rohu skin protein isolate 


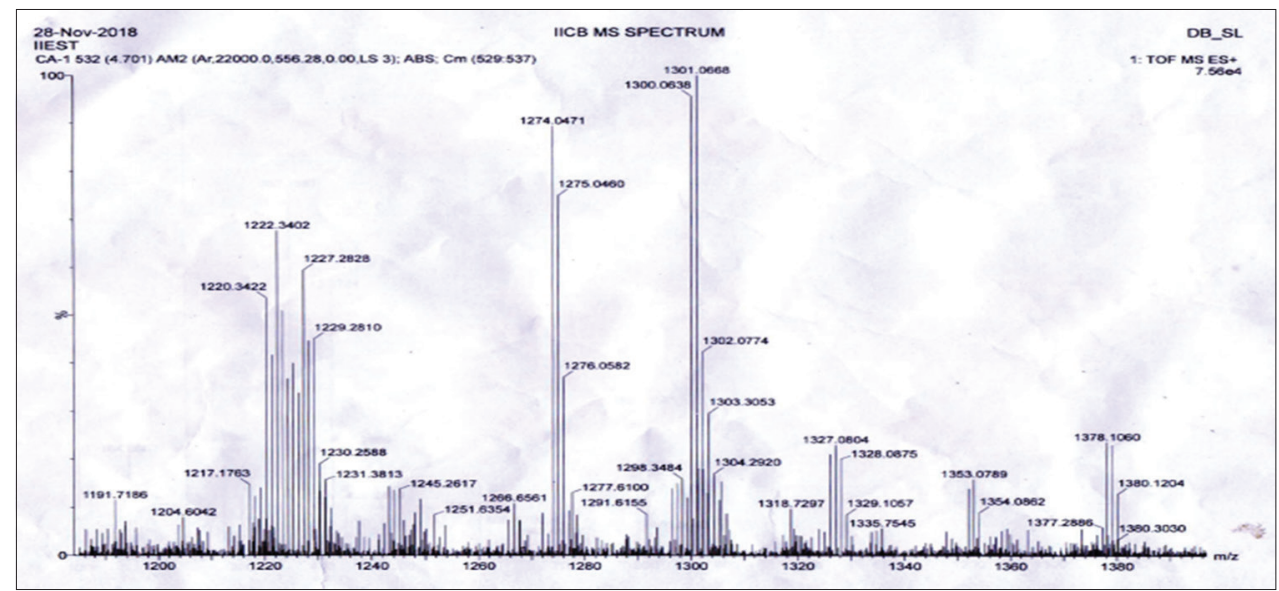

Fig. 6: Mass spectrum of Rohu skin protein isolate
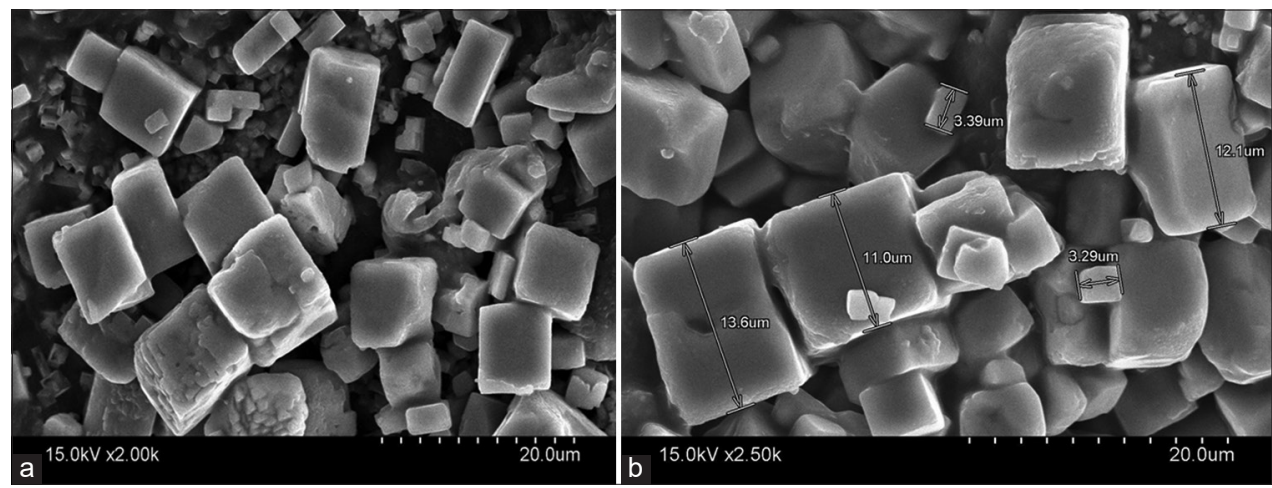

Fig. 7: ( $a$ and b) Scanning electron microscope of Rohu skin protein isolate

the fibrous nature of collagen. As the sample is in powder form it is showing a crystalline structure in SEM image.

\section{Antioxidative property analysis}

The antioxidative property of the protein isolate is mentioned in Table 2 .

\section{CONCLUSION}

Based on the tests performed Labeo rohita skin isolates can be claimed as type 1 collagen. Antioxidative properties were evaluated to know whether the FPI is oxidatively stable or not through different tests. The FPIs proved to have good antioxidative properties through DPPH, FRAP, ABTS, and reducing power assay. The results of all the tests performed lead to conclude that FPI can be used as an alternative source of collagen and can be used both in food formulation and pharmaceutical as a replacer of conventional collagen source.

\section{ACKNOWLEDGMENT}

The authors are thankful to the School of Community Science and Technology (SOCSAT), Indian Institute of Engineering Science and Technology (IIEST), Shibpur, for providing all the necessary equipment and reagents for conducting the work. Authors are also grateful to the Department of Chemistry, IIEST, Shibpur, for helping them in conducting FT-IR analysis, M. N. Dastur School of Materials Science and Engineering for SEM analysis, Central Instrumentation Facility, Indian Institute of Chemical Biology, Kolkata, for HPLC and MS analysis.

\section{AUTHORS' CONTRIBUTIONS}

Both the authors had contributed equally to the work. Nabanita Ghosh is a Ph.D. Research Scholar and D. K Bhattacharyya is the Principal Investigator of the work.

\section{CONFLICTS OF INTEREST}

The authors declare that there are no conflicts of interest.

\section{AUTHORS' FUNDING}

The contingency fund is provided by the SOCSAT lab, IIEST, Shibpur.

\section{REFERENCES}

1. Zhang F, Wang A, Li Z, He S, Shao L. Preparation and characterization of collagen from freshwater fish scales. Food Nut Sci 2011;2:818-23.

2. Sudharsan S, Seedevi P, Saravanan R, Ramasamy P, Kumar SV, Vairamani $\mathrm{S}$, et al. Isolation, characterization and molecular weight determination of collagen from marine sponge Spirastrella inoconstans (Dendy). Arf J Biotech 2013;12:504-11.

3. Blanco M, Vázquez JA, Pérez-Matín RI, Sotelo CG. Extraction optimization from the skin of the small-spotted catshark (S.canicula) by response surface methodology. Mar Drugs 2019;17:1-14.

4. Morimura S, Uemura Y, Kida K, Nagata H, Fahmi A, Shigematsu T. Development of an effective process for utilization of collagen from livestock and fish waste. Process Biochem 2002;37:1403-12.

5. Kolodziejska I, Sikorski ZE, Knwska N. Parameters affecting the isolation of collagen from squid (Illex argentimes) skins. Food Chem 1999;66:153-7.

6. Nagai T, Suzuki N. Preparation and characterization of several fish bone collagen. J Food Biochem 2000;24:427-36.

7. Swatscheck D, Schattoon W, Kellermann J, Mullar WE, Kreuter J. Marine sponge collagen: Isolation, characterization and effects on the skin parameter surface-ph, moisture and sebum. Eur J Pharm Biopharm 2002;53:107-13

8. Sadowska M, Kolodziejska I, Niecikowska C. Isolation of collagen from the skins of Baltic cod (Gadus morhua). Food Chem 2003;81: 257-62.

9. Vijayan DK, Sreerekha PR, Tejpal CS, Asha KK, Mathew S, Ravishankar $\mathrm{CN}$, et al. Extraction and characterization of acid soluble 
collagen (ASC) from air bladder of striped cat fish (Pangasius hypophthalmus). Int J Fish Aquat Stud 2018;6:310-8.

10. Ghosh N, Bhattacharyya DK. Effect of heating time and heat on the physicochemical and antioxidative property of fish (Labeo rohita) skin oil. Int J Pharm Pharm Sci 2019;11:87-9.

11. Ghosh N, Roy M, Ghosh M, Bhattacharyya DK. Study on Physicochemical and Antioxidant Properties of Blend of Fish Skin (Labeo rohita) Oil and Chia Seed (Salvia hispanica) Oil. Kolkata: $3^{\text {rd }}$ International conference on Biotechnology and Biological Sciences Biospectrum; 2019. p. 121-6.

12. Riaz T, Zeeshan R, Zarif F, Ilyas K, Muhammad N, Safi SZ, et al. FT-IR analysis of natural and synthetic collagen. Appl Spectro Rev
2018;53:703-46.

13. Belbachir K, Noreen R, Gouspillou G, Petibois C. Collagen types analysis and differentiation by FTIR spectroscopy. Anal Bioanal Chem 2009;395:829-37.

14. Pataridis S, Eckhardt A, Mikulíková K, Sedláková P, Miksík I. Determination and quantification of collagen types in tissues using HPLC-MS/MS. Curr Analyt Chem 2009;5 316-23.

15. Noitup P, Garnjanagoonchorn W, Morrissey, MT. Fish skin Type I collagen. J Aquat Food Prod Technol 2005;14:17-28.

16. Sujithra S, Kiruthiga N, Prabhu MJ, Kumeresan R. Isolation and determination of Type I collagen from tilapia (Oreochromis niloticus) waste. Int J Eng Technol 2013;5:2181-5. 